\title{
Induction of biomarkers associated with cadmium detoxification in aquatic species
}

\author{
A. A. El-Khatib ${ }^{1}$, A. K. Hegazy ${ }^{2}$, Amany, Abo-El-Kassem ${ }^{1}$ \\ ${ }^{1}$ Department of Botany, Faculty of Science, Sohag University, Egypt ${ }^{2}$ Department of Botany, Faculty \\ of Science, Cairo University, Egypt
}

Rec. 17 Sep, 2011 Accpt. 9 Oct, 2011

\begin{abstract}
The aquatic species Ceratophyllum demersum and Myriophyllum spicatum were grown in different $\mathrm{Cd}$ concentrations $(0,25,50,75 \mathrm{mg} / \mathrm{l})$ in a hydroponic system to analyze their detoxification capacity and the suitability of pigments and proline content to serve as biomarkers. Both studied species exhibited the same increasing pattern of $\mathrm{Cd}$ removal, when they treated with different $\mathrm{Cd}$ concentrations. M. spicatum exhibited a higher accumulation capacity than $C$. demersum being 1.5, 1.26 and 1.19 fold at the end of the experiment with the cadmium concentration of 25,50 and $75 \mathrm{mg} / \mathrm{l}$, respectively. Significant differences in pigment and proline contents between the treated and control samples indicated that $\mathrm{Cd}$ stress induced oxidative stress response in the studied species. Carotenoides and proline contents showed their partially increasing, especially during the short duration of $\mathrm{Cd}$ exposure. Chlorophylls a, -b exhibited the sever effects of Cd concentration on their contents. These responses reflected the suitability of the tested parameters to use them as biomarkers for heavy metal stress.
\end{abstract}

Keywords: Metals - Proline - Pigment - Phytoremediation - Hydrophytes

\section{Introduction}

Aquatic plants are well known for their potential to accumulate the heavy metals and they hold a prime position in food chain as primary producers, regulators of oxygen level. Aquatic plants play a significant role in biogeochemical cycling of toxic trace elements and are being increasingly considered for environmental phytomanagement (Sinha et al., 2002; Rai et al., 2004; Mishra et al., 2006). Aquatic macrophytes take up metals from the water, producing an internal concentration several folds greater than their surroundings. Many of the aquatic macrophytes are found to be the potential scavengers of heavy metals from water and wetlands (El-Khatib, 1991; ElKhatib and El-Sawaf, 1998; Ali and Soltan, 1999; Manal et al., 2011). Aquatic plants can be used as indicators of low-level environmental contamination that might otherwise be difficult to detect (Mazej and Germ, 2009). In aquatic ecosystem, cadmium is an important widespread trace pollutant, having large solubility in water thus poses greater risk to aquatic ecosystem, with high toxicity to plants, animals and humans (Toppi and Gabbrielli, 1999). Cadmium is released into the environment by power stations, heating systems, metal-working industries, nickel-cadmium batteries and phosphate fertilizers (Mishra et al., 2006), as well as from geochemical weathering of rocks. Despite its non-essentiality, cadmium is readily taken up by plants and can induce a number of physiological changes and phytotoxic symptoms including, chlorosis, growth inhibition, water imbalance, the inhibition of photosynthesis, phosphorus and nitrogen deficiency, reduced manganese transport and accelerated senescence (Mishra et al., 2006; Ding et al., 2007). It can enter chloroplasts and disturb chloroplast function by inhibiting the enzymatic activities of chlorophyll biosynthesis, pigment-protein complexes, O2-evolving reactions of photosystem II, electron flow around photosystem I and chloroplast structure (Siedlecka et al.,1997).Under Environmental stress such as heavy metal pollution, plants have shown proline accumulation (Ashraf and Foolad, 2007; Ahmad et al., 2008). It has been often suggested that proline accumulation may contribute to osmotic adjustment at the cellular level and enzyme protection

* Corresponding author:
Dr. A.A. El-Khatib
$\bowtie$ aaelkhatib@yahoo.com


stabilizes the structure of macromolecules and organelles. Proline, as a compatible solute is demonstrated to play role in maintenance of (a) cellular osmoticum; (b) NADPH/NAD $(\mathrm{P}+)$ ratio; and (c) cytosolic $\mathrm{pH}$, besides helping in detoxification of free radicals/toxic oxygen species (in particular singlet oxygen and hydroxyl radicals) (Alia and Saradhi, 1991; Alia et al., 1995).

Aquatic plant species used in the present study are Ceratophyllum demersum L. (Coontail or hornwort) and Myriophyllum spicatum L. They are known to be a good accumulator of Cd (Gupta et al, 1996; Rai et al., 1995; Arvind and Prasad, 2005; Mishra et al., 2006), and could be used in ecological surveys as in-situ biomonitors of water quality due to its ability to concentrate pollutants in their tissues and reflect the environmental pollution (Nimptsch et al., 2005). Accordingly, the aims of the present study was to:1)- compare the cadmium removal capacity of the two studied species; 2)- assess the using of pigment and proline contents of the two studied species as biomarkers reflecting the cadmium phytotoxicity.

\section{Material and methods}

\section{Plant material, growth conditions and} cadmium treatments

The studied species were $C$. demersum (family Ceratophyllaceae) and $M$. spicatum that taken from the main stream of the River Nile bank. C.demersum and M. spicatum (Haloragidaceae), and exposed to cadmium by growing the plants in hydroponic cultures in controlled environmental conditions. Before the experiment setup, whole plants of Ceratophyllum or Myriophyllum have thoroughly cleaned under running tap water to remove debris and other foreign particles, and then rinsed in bidistilled water. The plants transported to hydroponic culture and kept for 2 weeks in Hoagland nutrient solution to acclimatize, before adding the contaminants (Cowgill et al., 1989). Healthy acclimatized plants (100 g fresh weight each) left to grow in nutrient solution in the holding tank assigned for the different treatments. They divided in four sets, The first one acts as a control, while in the others the hydroponic solution is enriched with $\mathrm{Cd}\left(\mathrm{NO}_{3}\right) 2$ (Sigma, St. Louis, MO) up to 25,50, and $75 \mathrm{mg} / 1$.
Treated and control plants are sampled after 1 , 3,5 and 7 days for the experiment.

\section{Cadmium analysis}

Water samples of $15 \mathrm{ml}$ for each, were collected from all compartments at 1, 3, 5, and 7 days intervals for cadmium analyses. Atomic absorption spectrophotometer (AAS) Model 210 VGP Buck Scientific used for Cd analyses. Cadmium concentration values expressed as mg / L (ppm).Plant samples (5 g each) were collected at the start, at 3 days, 5 days and at the end of the experiment (7-day) and analyzed for the presence of cadmium. Harvested plants washed in distilled water, and then dried in a convection oven for $24 \mathrm{~h}$ at $48{ }^{\circ} \mathrm{C}$. After drying, the plants grounded to a fine powder. For analysis, dry plant material digested according to the wet digestion procedure involving concentrated nitric acid (Campbell and Plank, 1998). Ten ml concentrated nitric acid $\left(\mathrm{HNO}_{3}\right)$ and $0.5 \mathrm{ml}$ hydrofluoric acid (HF) added to $0.5 \mathrm{~g}$ of dry plant sample in a closed Teflon vessel, designed for the purpose at a temperature of $130{ }^{\circ} \mathrm{C}$ for $24 \mathrm{~h}$. Digestion in solution continues until clear. The resultant liquid diluted up to $25 \mathrm{ml}$ with distilled water then stored for analysis. Then, the $\mathrm{Cd}$ content was determined by the same Atomic absorption spectrophotometric method.

\section{Photosynthetic pigments and proline content}

The photosynthetic pigments, chlorophyll a (Chl a), chlorophyll b ( Chl b) and carotenoids were determined according to (Lichtenthaler, 1987). The absorbance of pigment extract measured at wavelength of $452.5,644$ and $663 \mathrm{~nm}$ with spectrophotometer (Unico ${ }^{\circledR} \quad 1200$ spectrophotometer). The concentrations of pigments (chl.a, chl.b, and cartotenoids) calculated on a fresh weight basis and expressed as $\mathrm{mg} / \mathrm{g} \mathrm{FW}$. (Bates et al., 1973). method used to determine proline content in the tissues of the studied species. Proline separated by addition of toluene and quantified by a spectrophotometer method using Unico ${ }^{\circledR} \quad 1200$ spectrophotometer, at $520 \mathrm{~nm}$. Proline content expressed as $\mathrm{mg} / \mathrm{g}$ dry weight (DW). 


\section{Statistical analysis}

Controls and treatments were performed in triplicate. Data were tested for statistical significance using the software of SPSS15.0 for Windows, followed by the MANOVA test for comparison of means of the tested parameters. The difference was considered significant at the $P<0.01$ level. In addition, regression and correlation coefficients for the tested parameters were computed.

\section{Results}

Figure (1a) shows the increasing trend of Cd removal by the studied species with the increasing of time in all the experimental sets. Concerning $C$. demersum, the amount of $\mathrm{Cd}$ remains in the nutrient solution reached to $30.8 \%, 20.7 \%$ and $37.5 \%$ at the end of the experiment for initial $\mathrm{Cd}$ treatments of 25,50 and $75 \mathrm{mg} / \mathrm{l}$, respectively. Meanwhile, in the case of $M$. spicatum, the situation was $13.2 \%$, $12.86 \%$ and $11.1 \%$ for initial $\mathrm{Cd}$ treatments of 25,50 and $75 \mathrm{mg} / 1$, respectively. Figure (1b) shows the removal efficiency of $\mathrm{Cd}$ by the studied species. It is noticeable, that $M$. spicatum attained the highest $\mathrm{Cd}$ removal efficiency in all the experimental sets, with all initial treatments $25,50,75 \mathrm{mg} / \mathrm{l}$. It attained the highest removal efficiency $88.67 \%$ at the highest treatment $75 \mathrm{mg} / \mathrm{l}$ by the end of the experiment. On the other side, the removal efficiency of $C$. demersum varied between $18.02 \%$ (1-day) and $79.14 \%$ (7- day), when initial concentration of $50 \mathrm{mg} / \mathrm{l} \mathrm{Cd}$ was used. Figure (1c) shows cadmium uptake by $C$. demersum and $M$. spicatum. At the experiment setup, the initial concentration of $\mathrm{Cd}$ in the tissues of both species was 0.017 $\mathrm{mg} / \mathrm{g}$ DW for $C$. demersum and $0.016 \mathrm{mg} / \mathrm{g}$ DW for M. spicatum. Both species exhibited the same pattern accumulation, when they treated with different $\mathrm{Cd}$ concentratio the accumulation capacity of the two studied species exhibited significant differences $(\mathrm{P}<0.01)$ when different treatments were used. Higher accumulation values of 82.70 and $69.22 \mathrm{mg} / \mathrm{g} \mathrm{DW}$ ) were attained by $M$. spicatum and $C$. demersum, respectively, at 7 $\mathrm{d}$, when $\mathrm{Cd}$ initial concentration of $75 \mathrm{mg} / \mathrm{l}$ was applied.

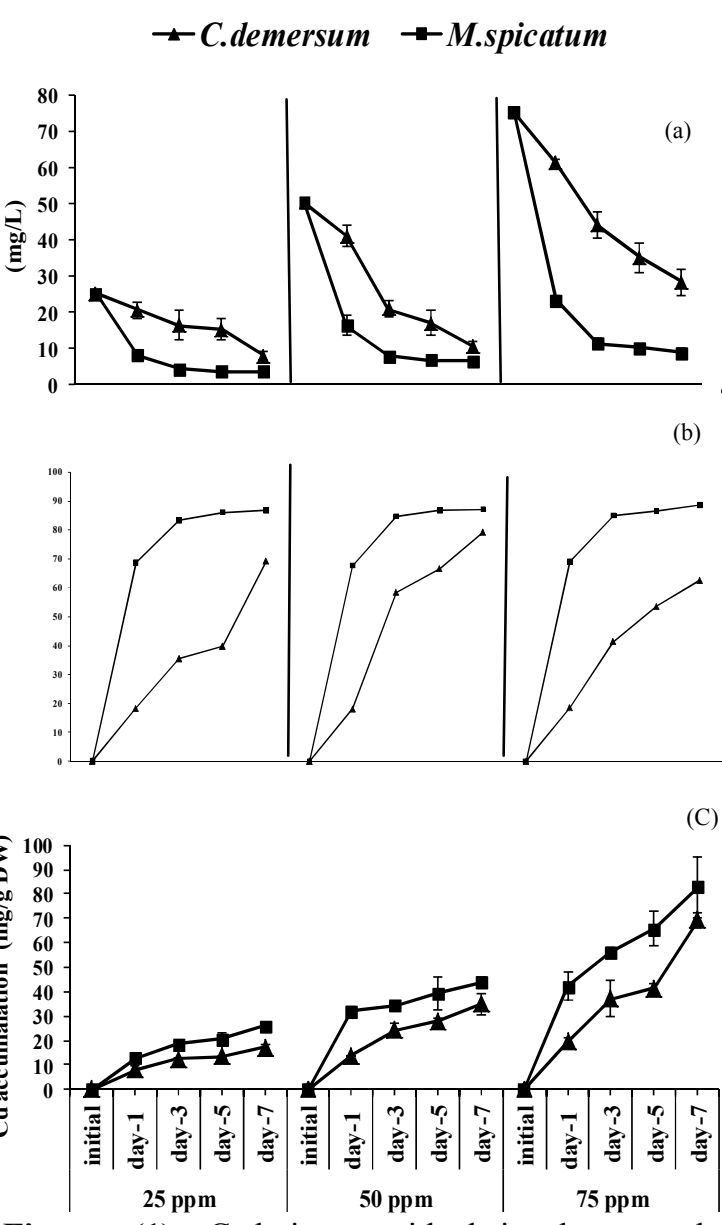

Figure. (1): Cadmium residual in the growth media (a), Removal efficiency of cadmium (b) and $\mathrm{Cd}$ accumulation by $C$. demersum and $M$. spicatum (c) with different $\mathrm{Cd}$ treatments during the experiment duration

Figure (2a-c) illustrates the changes in the photosynthetic pigments (chl a, chl b, and Carotenoid) in the leaves of the studied species due to cadmium detoxification. Chlorophyll concentrations in the studied species were drastically decreased with increasing $\mathrm{Cd}$ concentrations in the nutrient medium (Figure 2a-b). Compared to the control, the chlorophyll concentrations in the studied species were significantly different $(P<0.01)$. Upon cadmium exposure, chlorophyll $\mathrm{a}$ and $\mathrm{b}$ content in the two studied species exhibited similar response with a gradual declining trend at all $\mathrm{Cd}$ concentrations. The maximum decline noticed after $7 \mathrm{~d}$ in the two tested species. Increase of $\mathrm{Cd}$ concentration in the nutrient media expressed significant effect $(P<0.01)$ on the production of chlorophylls in the studied species, where at higher $\mathrm{Cd}$ concentration $(75$ $\mathrm{mg} / \mathrm{l}$ ), chlorophyll a content reached its minimum values, being $36.18 \mathrm{mg} / \mathrm{g} \mathrm{FW}$ ( $C$. 
demersum) and $34.6 \mathrm{mg} / \mathrm{g}$ FW ( $M$. spicatum), at the end of experiment. The same is true for chlorophyll $b$, where minimum

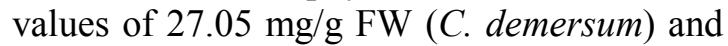
$31.80 \mathrm{mg} / \mathrm{g} \mathrm{FW}$ (M. spicatum) were recorded. Carotenoids contents of both two species showed contrast behavior to the chlorophyll content during the short duration of the experiment at the different medium concentration, except those of $C$. dermersum at $75 \mathrm{mg} / \mathrm{l}$, where they showed a decreasing trend as those of chlorophylls (Fig 2c). After $7 \mathrm{~d}$ of the experiment setup, the carotenoids contents of the two species decreased to reach its minimum values of $14.40 \mathrm{mg} / \mathrm{g} \mathrm{FW}(C$. demersum) and $23.60 \mathrm{mg} / \mathrm{g}$ FW ( $M$. spicatum). The two species exhibited maximum values of carotenoids contents at initial $\mathrm{Cd}$ concentration of $25 \mathrm{mg} / 1$, after $3 \mathrm{~d}$, being $76.90 \mathrm{mg} / \mathrm{g} \mathrm{FW} \mathrm{(C.} \mathrm{demersum)} \mathrm{and}$ $102.97 \mathrm{mg} / \mathrm{g} \mathrm{FW}$ (M. spicatum).

$\rightarrow$ C. demersum $\rightarrow$ M. spicatum
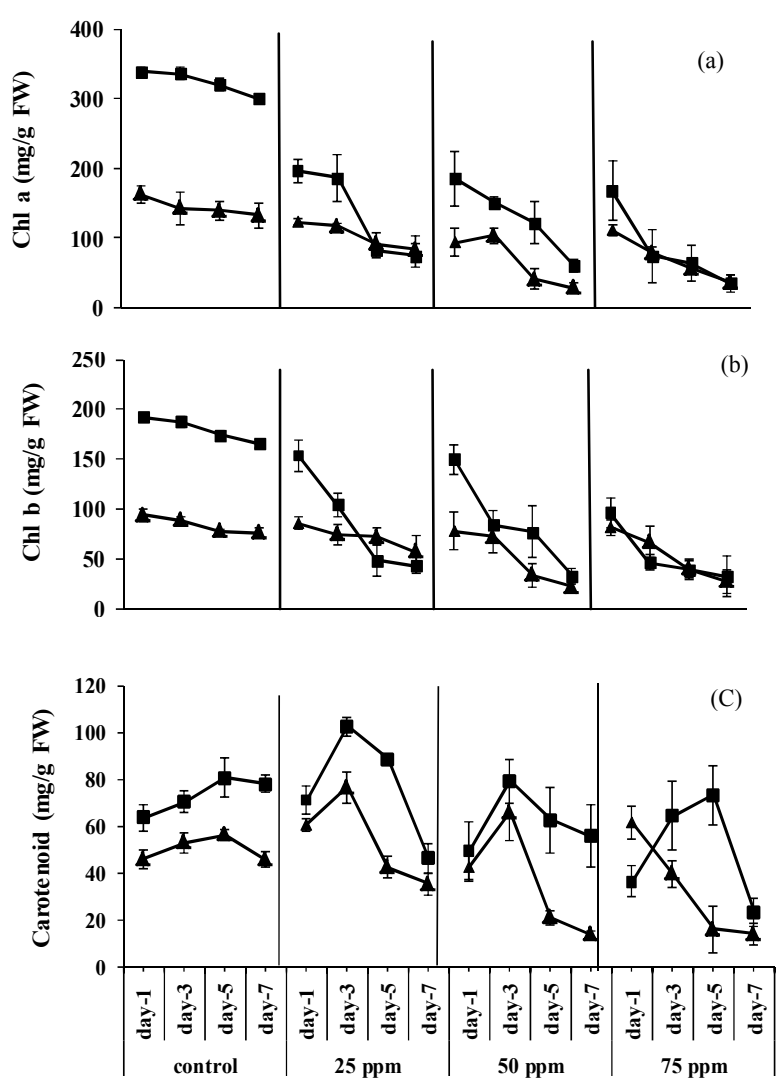

Figure. (2): Effect of cadmium treatment on photosynthetic pigments, chlorophyll a (a), chlorophyll b (b), and carotenoid (c) of C.demersum and M.spicatum.

The stress indicator amino acid proline content increased with the increase in the concentration of cadmium in the nutrient medium until initial $\mathrm{Cd}$ concentration of 50 $\mathrm{mg} / \mathrm{L}$ (Figure 3). Compared to the control plants, the content of proline in the two studied species growing at $25 \mathrm{mg} / \mathrm{L}$ continued to increase significantly $(P<0.01)$ until the end of experiment, where the proline content of $M$. spicatum was higher than those of $C$. demersum. At $50 \mathrm{mg} / \mathrm{L}$, proline contents of the two studied species exhibited decline trend reaching its minimum values of 1.26 and $2.79 \mathrm{mg} / \mathrm{g} \mathrm{DW}$, after $7 \mathrm{~d}$, in $C$. demersum and $M$. spicatum, respectively. At $75 \mathrm{mg} / \mathrm{L}$, the two species exhibited their minimum values of $1.34 \mathrm{mg} / \mathrm{g}$ DW (C. demersum) and $3.11 \mathrm{mg} / \mathrm{g}$ DW (M. spicatum), at $7 \mathrm{~d}$ experiment.

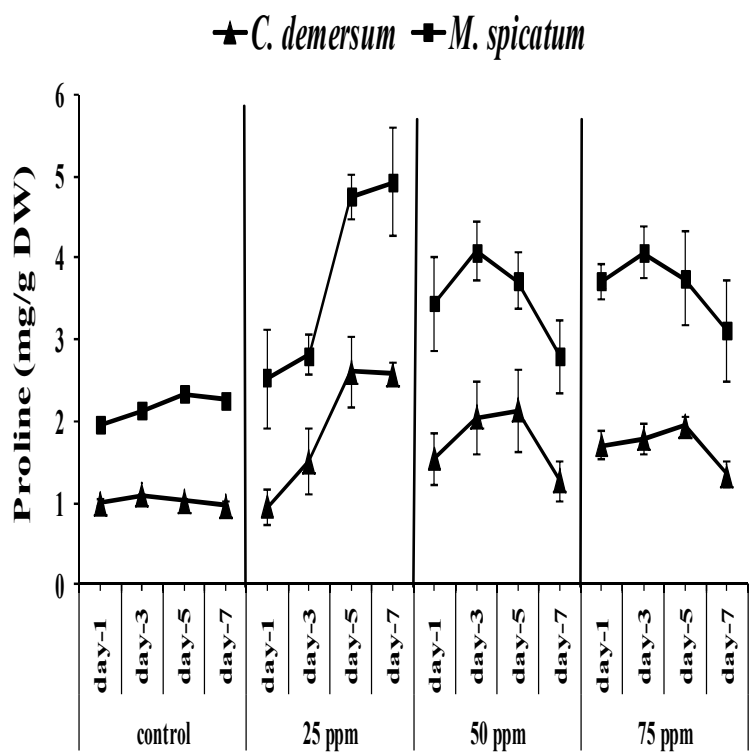

Figure. (3): Proline content by $C$. demersum and $M$. spicatum growing in growth media with different $\mathrm{Cd}$ treatments during the experiment duration.

\section{Discussion}

It is clear that the residual of $\mathrm{Cd}$ in growth media was greater in $C$. demersum and consequently, the highest removal of $\mathrm{Cd}$ recorded in $M$. spicatum under the three experiment treatments. The variation in the $\mathrm{Cd}$ concentrations indicated a highly significant difference $(P<0.001)$ between the two studied species. The regression coefficient $\left(\mathrm{R}^{2}=18.2 \%\right)$ denoted the pronounced impact between the uptake and increasing $\mathrm{Cd}$ concentration in the medium, where the two studied species accumulated high amount of $\mathrm{Cd}$ in a dose dependent manner. Although, cadmium accumulation observed higher in $M$. spicatum than $C$. 
demersum, a general increase in $\mathrm{Cd}$ accumulation in a given species occurs with an increasing $\mathrm{Cd}$ concentration in the nutrient media. The accumulation of $\mathrm{Cd}$ was the lowest at the $1 \mathrm{~d}$ treatment and the highest at the $7 \mathrm{~d}$. All above-mentioned findings reveal that a mass balance should be given between cadmium accumulation in a species and cadmium removal from aqueous treatment solution. High significant difference in accumulation of $\mathrm{Cd}(P<0.01)$ was recorded between two studied species. In their study, (Cardwell et al., 2002). stated that the extent of metal accumulation within aquatic macrophytes is variable and depends on the type of plant species.

Generally, the two studied species exhibited high $\mathrm{Cd}$ accumulation capacity. This may be due to the two studied species are fully submerged, floating plants with narrow leaves and no root shoot partitioning. This feature provides large surface area for metal removal, which results in high accumulation. In comparison, M. spicatum expressed a higher accumulation capacity than $C$. demersum being 1.5, 1.26 and 1.19 fold on the end of the experiment at cadmium concentration of 25 , 50 and $75 \mathrm{mg} / \mathrm{L}$, respectively. Consequently, high concent-ration factor [metal content in plant tissue $(82.71 \mathrm{mg} / \mathrm{g}$ DW $) /$ metal content in growth solution $(75 \mathrm{mg} / \mathrm{L})$ ] for $M$. spicatum reflects its high accumulation potential, which is an essential factor for phytoremediation (Andra et al., 2010).

$\mathrm{Cd}$ stress causes many physiological changes in growing plants. Decrease in the chlorophylls is the primary bioindicator of $\mathrm{Cd}$ phytotoxicity. In comparison with those of control, chl a, and b content of the treated species showed decline trends, especially at higher $\mathrm{Cd}$ concentration, where after $7 \mathrm{~d}$, a drastic reduction in chls content was observed at cadmium concentration of $75 \mathrm{mg} / \mathrm{L}$ in the nutrient solution. In the present study, the effects of $\mathrm{Cd}$ treatments were significantly varied $(P<0.01)$ from those of control. Both chlorophyll a and b contents in the two studied species exhibited similar response, with a gradual decline trend, at all exposure concentrations and durations. As reported in many studied (Macfarlane and Burchett, 2001; Sinha et al., 2005; Mishra et al., 2006; Srivastava et al., 2006; Mishra and Tripathi, 2008). the content of photosynthetic pigments, including chl- $\mathrm{Cd}$ stress causes many physiological changes in growing plants. Decrease in the chlorophylls is the primary bioindicator of $\mathrm{Cd}$ phytotoxicity. In comparison with those of control, chl a, and b content of the treated species showed decline trends, especially at higher $\mathrm{Cd}$ concentration, where after $7 \mathrm{~d}$, a drastic reduction in chls content was observed at cadmium concentration of $75 \mathrm{mg} / \mathrm{L}$ in the nutrient solution. In the present study, the effects of $\mathrm{Cd}$ treatments were significantly varied $(P$ $<0.01$ ) from those of control. Both chlorophyll $\mathrm{a}$ and $\mathrm{b}$ contents in the two studied species exhibited similar response, with a gradual decline trend, at all exposure concentrations and durations. As reported in many studied (Macfarlane and Burchett, 2001; Sinha et al., 2005; Mishra et al., 2006; Srivastava et al., 2006; Mishra and Tripathi, 2008), the content of photosynthetic pigments, including chl-a, $\mathrm{b}$ in their tested species reduced due to exposure to heavy metals including $\mathrm{Cd}$. The mechanisms of this reduction documented as inhibition of enzymes involved in chlorophyll biosynthesis (Chandra and Kulshreshtha, 2004; Baryla et al., 2001; Benavides et al., 2005; Srivastava et al., 2006). impaired uptake of essential elements such as $\mathrm{Mn}$ and $\mathrm{Fe}$ (Somashekaraiah et al., 1992). and reduction in chloroplast density and size (Baryla et al., 2001; Benavides et al., 2005). In the present study, carotenoids content of both studied species showed contrast behavior to the chlorophyll content, during the short duration of the experiment. Carotenoids content of $C$. demersum and $M$. spicatum showed the highest values after $3 \mathrm{~d}$ at $\mathrm{Cd}$ concentration of $25 \mathrm{mg} / \mathrm{L}$. While, the minimum value recorded by the end of the experiment at $\mathrm{Cd}$ concentration of $75 \mathrm{mg} / \mathrm{L}$. The increase in the carotenoid level may be due to the ability of the plant to counteract the toxic effect of free radicals generated under stress (Toppi and Gabbrielli, 1999). The recorded decline in carotenoides contents with increase in metal concentrations reported as a common occurrence observed in several aquatic plants with other metals (Rai et al., 1995; Sinha et al., 2002). Generally, the computed negative correlation coefficient $(-0.326)$ proved the inverse relationship between metal concentration and carotenoides content, especially 
with long duration of $\mathrm{Cd}$ exposure. $\mathrm{a}, \mathrm{b}$ in their tested species reduced due to exposure to heavy metals including $\mathrm{Cd}$. The mechanisms of this reduction documented as inhibition of enzymes involved in chlorophyll biosynthesis (Chandra and Kulshreshtha, 2004; Baryla et al., 2001; Benavides et al., 2005; Srivastava et al., 2006). impaired uptake of essential elements such as $\mathrm{Mn}$ and $\mathrm{Fe}$ (Somashekaraiah et al., 1992), and reduction in chloroplast density and size (Baryla et al., 2001; Benavides et al., 2005). In the present study, carotenoids content of both studied species showed contrast behavior to the chlorophyll content, during the short duration of the experiment. Carotenoids content of $C$. demersum and $M$. spicatum showed the highest values after $3 \mathrm{~d}$ at $\mathrm{Cd}$ concentration of $25 \mathrm{mg} / \mathrm{L}$. While, the minimum value recorded by the end of the experiment at $\mathrm{Cd}$ concentration of $75 \mathrm{mg} / \mathrm{L}$. The increase in the carotenoid level may be due to the ability of the plant to counteract the toxic effect of free radicals generated under stress (Toppi and Gabbrielli, 1999). The recorded decline in carotenoides contents with increase in metal concentrations reported as a common occurrence observed in several aquatic plants with other metals (Rai et al., 1995; Sinha et al., 2002). Generally, the computed negative correlation coefficient $(-0.326)$ proved the inverse relationship between metal concentration and carotenoides content, especially with long duration of $\mathrm{Cd}$ exposure.

Accumulations of $\mathrm{Cd}$ in the tissues of studied species were accompanied by concomitant induction in the levels of antioxidants (proline). Proline accumulation is not only regarded as an indicator of environmental stress but also considered as an important protective role against heavy metal stress (Sharma et al., 1998). In the present study, the proline level increased by two and three-fold over that of control in $C$. demersum and $M$. spicatum in response to different concentrations of cadmium. These results are in agreement with those of Dinakar et al. (2008). who reported that Cd treated plant showed a significant increase in proline as compared to the control samples. Most heavy metals cause oxidative stress via generation of ROS (Dietz et al. 1999). It has been proposed that proline act as a free radical scavenger to protect plants away from damage by oxidative stress (Alia and Matysik. 2001). In addition, (Smain et al., 2009). reported that, cadmium, copper, and zinc induced an increase of proline contents in L. gibba and concluded that, the amplitude of proline changes was very important and could be a very good indicator of toxicity. It has been demonstrated that free proline could chelate with $\mathrm{Cd}$ ion in plants and form a nontoxic $\mathrm{Cd}$ proline complex (Sharma et al., 1998). Accordingly, the increase in proline levels in the present study with increasing $\mathrm{Cd}$ concentration might consider as an indicator on a correlation between ROS generation (hydroxyl radicals mostly) and ROS scavenging by proline. This is stem up from the positive value $(0.216)$ of correlation coefficient, which added an evident for this relationship.

Although a significant variation $(P<0.01)$ in accumulation value of proline was recorded between the two studied species, the two species often display the same pattern. The maximum proline accumulation was recorded at $25 \mathrm{mg} / 1 \mathrm{Cd}(4.93 \mathrm{mg} / \mathrm{g} \mathrm{DW})$ in $M$. spicatum after $7 \mathrm{~d}$. Generaly, M. spicatum had more proline content than $C$. demersum. This suggests that the hyperaccumulator, $M$. spicatum has stronger self-protection ability than $C$. demersum. The time-response curves displayed the same pattern with an increase followed by a decrease in proline contents, where, proline accumulation decreased after 3 $\mathrm{d}$, at initial $\mathrm{Cd}$ concentration 50 and $75 \mathrm{mg} / \mathrm{L}$. This is in agreement with the results of (Smain Megateli et al., 2009). in their study stated that the kinetics of the response showed a maximum proline accumulation after 4 days, which was followed by a decrease of the contents back to values close to those of the control after $7 \mathrm{~d}$.

\section{References}

Ahmad, P., John, R., Sarwat, M., Umar, S. (2008). Responses of proline, lipid peroxidation and antioxidative enzymes in two varieties of Pisum sativum L. under salt stress. International Journal of Plant Production, 2: 353-366.

Ali, M.M., Soltan, M.E. (1999). Heavy metals in aquatic macrophytes, water and hydrosoils from the River Nile, Egypt. J. Union Arab. Biol, Cairo 9(B): 99-115.

Alia, and Saradhi, P.P. (1991). Proline accumulation under heavy metal stress. J. Plant Physiol. 138: 554-558. 
Alia, and Matysik, J. (2001). Effect of proline on the production of singlet oxygen. Amino Acids 21: 195-200. doi:10.1007/s007260 170026

Alia, Prasad, K.V.S.K., Pardha Saradhi, P. (1995). Effect of zinc on free radicals and proline in Brassica and Cajanus. Phytochemistry 39: 45-47.

Andra, S.S., Datta, R., Sarkar, D., Makris, K.C., Mullens, C.P., Sahi, S.V., Bach, S.B.H. (2010). Synthesis of phytochelatins in vetiver grass upon lead exposure in the presence of phosphorus. Plant and Soil, 326, 171-185.

Arvind, P. and Prasad, M.N.V. (2005). Cadmiumzinc interactions in a hydroponic system using Ceratophyllum demersum L.: adaptive ecophysiology, biochemistry and molecular toxicology. Braz. J. Plant Physiol. 17: 3-20.

Ashraf, M. and Foolad, M.R. (2007). Roles of glycine betaine and proline in improving plant abiotic stress resistance. Environ. Exp. Bot. 59:206-216

Baryla, A., Carrier, P., Franck, F., Coulomb, C., Sahut, C., Havaux, M. (2001). Leaf chlorosis in oilseed rape plants (Brassica napus) grown on cadmium-polluted soil causes and consequences for photosynthesis and growth. Planta, 212: 696-709.

Bates, L.S., Waldren, R.P., Teare, I.D. (1973). Rapid determination of free proline for water-stress studies. Plant Soil. 39: 205-207.

Benavides, M.P., Gallego, S.M., Tomaro, M.L. (2005). Cadmium toxicity in plants. Braz. J. Plant Physiol. 17:21-34.

Campbell, C.A., and Plank, C.O. (1998). Preparation of plant tissue for laboratory analysis. In: Kalara, Y.P. (Ed.), Handbook of Reference Methods for Plant Analysis. CRC Press LLC, Boca Raton.

Cardwell, A., Hawker, D., Greenway, M. (2002). Metal accumulation in aquatic macrophytes from Southeast Queensland, Australia. Chemosphere 48: 653-663.

Chandra, P and Kulshreshtha, K. (2004). Chromium accumulation and toxicity in aquatic vascular plants. Bot. Rev. 70: 313327.

Cowgill, U.M. and Milazzo, D.P. (1989). "The culturing and testing of two species of duckweed," Aquatic Toxicology and Hazard Assessment: 12th Volume, ASTM STP 1027, U.M. Cowgill and L.R. Williams, Eds. American Society for Testing and materials, Phila., : 379-391.

Dietz, K.J., Bair, M., Kramer, U. (1999). Free radicals and reactive oxygen species as mediators of heavy metals toxicity in plants. In: Prasad, M.N.V., Hagemeyer, J. (Eds.), Heavy Metal Stress in Plants: from
Molecules to Ecosystems. Springer-Verlag, Berlin, pp. 73-97.

Dinakar, N., Nagajyothi, P.C., Suresh, S., Udaykiran, Y., Damodharam, T. (2008). Phytotoxicity of cadmium on protein, proline and antioxidant enzyme activities in growing Arachis hypogaea L. seedlings. J. Environ. Sci., 20:199-206.

Ding, B.Z., Shi, G.X., Xu, Y., Hu, J.Z., Xu, Q.S. (2007). Physiological responses of Alternanthera philoxeroides (Mart.) Griseb leaves to cadmium stress. Environ. Pollut. 147: 800-803.

El-Khatib, A.A. (1991). Ecological studies on the Hydrophytes and their Epiphytic Algae in relation to water pollution at Sohag area, Eygpt. M. Sc. Fac.Sci. Sohag, Assiut University, Egypt.

El-Khatib, A.A. and El-Sawaf, N. (1998). Differential trapping of heavy metals by macrophytes in different water bodies near Sohag, Upper Egypt. Acta Hydrobiol, 2: 6773.

Gupta, M., Sinha, S., Chandra, P. (1996). Copperinduced toxicity in aquatic macrophyte: Hydrilla verticillat effect of $\mathrm{pH}$. Ecotoxicology 5: 23-33.

Knox, J.P. and Dodge, A.D. (1985). Singlet oxygen and plants. Phytochemistry 24:889896.

Lichtenthaler, H.K. (1987). Chlorophyll and carotenoids, pigments of photosynthetic biomembranes. Methods Enzymol. 148: 350382.

Macfarlane, G.R. and Burchett, M.D. (2001). photosynthetic pigments and peroxidase activity as indicators of heavy metal stress in the greymangrove, Avicennia marina (Forsk.)Vierh. Mar. Pollut. Bull. 42: 233-40.

Manal, A.F., Nadia, B.E., El-Khatib, A.A., Amany, A. ( 2011). Heavy metal biomonitoring and phytoremediation potentialities of aquatic macrophytes in River Nile. Environ Monit Assess

Mazej, Z. and Germ, M. (2009). Trace element accumulation and distribution in four aquatic macrophytes. Chemosphere 74: 642-647.

Mishra, V.K. and Tripathi, B.D. (2008). Concurrent removal and accumulation of heavy metals by three aquatic macrophytes. Bioresource Technol. 99: 7091-7097.

Mishra, S., Srivastava, S., Tripathi, R.D., Kumar, R., Seth, C.S., Gupta, D.K. (2006). Lead detoxification by coontail (Ceratophyllum demersum L.) involves induction of phytochelatins and antioxidant system in response to its accumulation. Chemosphere 65: 1027-1039.

Nimptsch, J., Wunderlin, D.A., Dollan, A., Pflugmacher, S. (2005). Antioxidant and 
biotransformation enzymes in Myriophyllum quitense as biomarkers of heavy metal exposure and eutrophication in Suquia River basin (Cordoba, Argentina). Chemos 61: 147-157.

Rai, U.N., Tripathi, R.D., Gupta, M., Chandra, P. (1995). Induction of phytochelatins under cadmium stress in water lettuce (Pistia stratiotes L.). J. Environ. Sci. Health A 30 (9), 2007-2026.

Rai, V., Vajpayee, P., Singh, S.N., Mehrotra, S. (2004). Effect of chromium accumulation on photosynthetic pigments, oxidative stress defense system, nitrate reduction, proline level and eugenol content of Ocimum tenuiflorum L.. Plant Sci. 167: 1159-1169.

Rice-Evans, C.A., Miller, N.J., Paganga, G. (1996). Structure-antioxidant activity relationships of flavonoids and phenolic acids. Free Radic. Biol. Med. 20: 933-956.

Sharma, P.K. and Hall, D.O. (1992). 'Changes in carotenoid composition and photosynthesis in Sorghum under high light and salt stress', Ind. J. Plant Physiol. 140: 661-666.

Siedlecka, A., Krupa, Z., Samuelsson, G., O“quist, G., Gardestrom, P.(1997).Primary carbon metabolism in Phaseolus vulgaris plants under $\mathrm{Cd}(\mathrm{II}) / \mathrm{Fe}$ interaction. Plant Physiol. Biochem.35:951-957.

Sinha, S., Saxena, R., Singh, S. (2002). Comparative studies on accumulation of $\mathrm{Cr}$ from metal solution and tannery effluent under repeated metal exposure by aquatic plants: its toxic effects. Environ. Monit. Assess. 80 (1): 17-31.

Sinha, S., Saxena, R., Singh, S. (2005). Chromium induced lipid peroxidation in the plants of Pistia stratiotes L.: role of antioxidants and antioxidative enzymes. Chemosphere 58: 595-604.

Smain, M., Saida, S., Michel, C. (2009). Toxicity and removal of heavy metals (cadmium, copper and zinc) by Lemna gibba. Ecotoxicology and Environmental Safety 72: 1774-1780

Somashekaraiah, B.V., Padmaja, K., Prasad, A.R.K. (1992). Phytotoxicity of cadmium ions on germinating seedlings of Mung bean (Phaseolus vulgaris): involvement of lipid peroxides in chlorophyll degradation. Physiol. Plant. 63: 85-89.

Srivastava, S., Mishra, S., Tripathi, R.D., Dwivedi, S., Gupta, D.K. (2006). Copper induced oxidative stress and responses of antioxidants and phytochelatins in Hydrilla verticillata. Aquatic Toxicol. 80: 405-415.

Toppi, S.D.L. and Gabbrielli, R. (1999). Response to cadmium in higher plants. Exp. Bot. 41: 105-130.

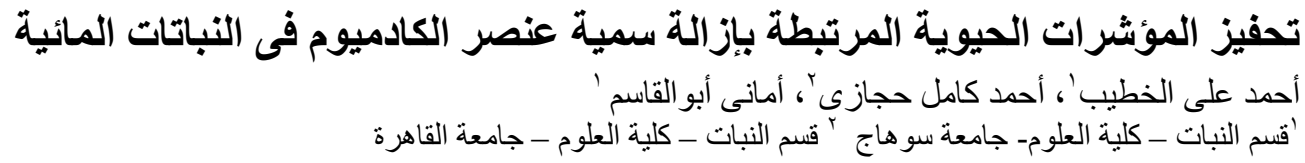

الملخص العربي توزي

تم زر اعـة نـو عين مـن النباتـات المائيسة هديا نبـات السير اتوفيلم (Ceratophyllum demersum ) و نبـات الميروفيلم (Myriophyllum spicatum)

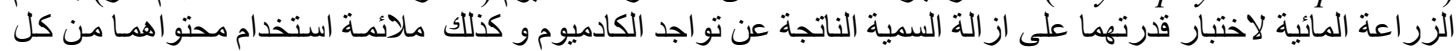

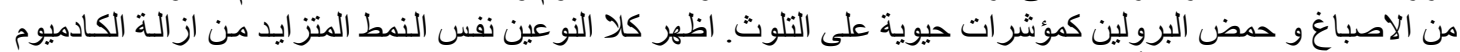

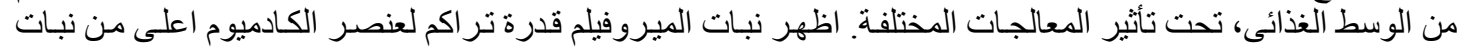

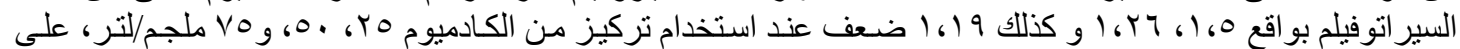

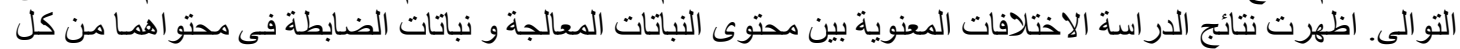

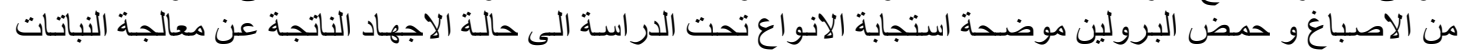

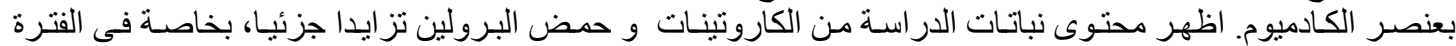

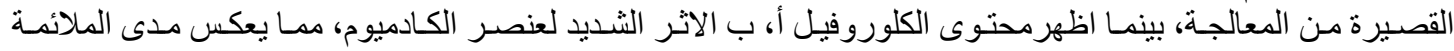
لاستخدامها كمؤشر ات حيوية للالالة على حالة التلوث الناتجة عن العناصر الثقيلة. 